\title{
急性期病院における理学療法対象者の血圧脈波 検査装置を用いた動脈硬化の調査とその活用
}

\author{
Investigation of Arteriosclerosis with a Noninvasive Cardiovascular Device \\ in Physical Therapy Subjects
}

\begin{tabular}{|c|c|c|}
\hline 董 1,3$)$ & 大平 高正1) & 薬師寺里江 ${ }^{1)}$ \\
\hline 純1) & 井上 博文 ${ }^{1)}$ & 秋山 純和 2$)$ \\
\hline
\end{tabular}

KAORU YAMANO, RPT, MA ${ }^{1,3)}$, TAKAMASA OHIRA, RPT ${ }^{1)}$, RIE YAKUSHIJI, Ns ${ }^{1 \text {, }}$ Atsushi TOGOU, RPT ${ }^{1)}$, HiROFUMi INOUE, MD ${ }^{1)}$, SUMIKAZU AKIYAMA, RPT, PhD ${ }^{1)}$

1) Department of Rehabilitation Medicine, Oita Prefectural Hospital: 476 Bu-nyo, Oita City, Oita 870-8511, Japan. TEL +81 97-546-7227

2) Department of Physical Thetapy, Faculty of Health Science, International University of Health Welfare

3) Division of Physical Therapy, Doctoral Program in Health Sciences, Health and Sciences Course, International University of Health Welfare Graduate School

Rigakuryoho Kagaku 22(4): 433-437, 2007. Submitted Feb. 13, 2007. Accepted May 11, 2007.

\begin{abstract}
We measured the cardio ankle vascular index (CAVI) using a pulse wave test instrument for 47 patients who had requested physical therapy for disorders of their bone joints, cerebral blood vessels and cardiovascular diseases. CAVI, which indicates the tendency of arterial sclerosis in the extremities, showed significant differences between two groups: one suffering from more than two disorders out of high blood pressure, angina cordis and diabetes, and the other being the other patients' group. The former group also showed significant differences with or without a history of angina cordis. These results may show the development of serious disturbances of peripheral circulation or coronary artery diseases, indicating a need for caution when conducting therapeutic exercises. Compulsory pulse wave testing before therapeutic exercises could possibly provide beneficial information on exercise load.
\end{abstract}

Key words: pulse wave test, risk management, physical therapy

要旨: 骨関節, 脳血管, 循環器などの各疾患で理学療法依頼のあった47人を対象に, 血圧脈波検査装置を用い, Cardio Ankle Vascular Index（CAVI）を測定し検討した。CAVIは，四肢の動脈硬化傾向を示すものであり，高血圧，狭心症， 糖尿病の3疾患のうち，2つ以上の疾患に罹患している群とそれ以外の群で有意差を認め, 狭心症既往の有無でも有意 差を認めた。このことは, 重篤な未梢循環障害や冠動脈疾患へ発展する可能性を示しており, 運動療法を実施する上 で注意が必要なことを意味している。運動療法前に血圧脈波検査を施行することは，運動負荷における有益な一情報 と考えられた。

キーワード：血圧脈波検查, リスクマネジメント, 理学療法

1) 大分県立病院 リハビリテーション科：大分県大分市ぶによう476（†870-8511）TEL 097-546-7227

2) 国際医療福祉大学 保健医療学部理学療法学科

3) 国際医療福祉大学大学院医療福祉学研究科保健医療学専攻理学療法学分野

受付日 2007年2月13日＼cjkstart受理日２007年5月11日 


\section{I. 研究背景}

多くの医療機関の理学療法部門では, さまざまな理由 によるインシデント・アクシデントが発生している1-3)。 運動療法には, 治療手段としての運動負荷がもたらすス トレスが存在することは否定できない。患者の機能や能 力を伸ばすこととリスクの存在は表裏一体である。機能 や能力の回復を目指すあまり, 生命予後にも直結するよ うなアクシデントを無視することはあってはならないこ とである。

高齢化により循環器疾患を持つ対象者が増加してい る。特に, 動脈硬化は循環器系 (高血圧, 高脂血症), 内 分泌系（糖尿病）の疾患と相互関係があり，重篤な疾病 に進行し，死亡率も高く推移している疾患である。牧田 ${ }^{4}$ は，わが国の死因の第1位は悪性新生物（癌）であるが, 2位と3位は心疾患と脳血管疾患であり，この両者を合わ せるとほぼ1位の悪性新生物に匹敵し, その病態の主体が 動脈硬化症であると述べている。

理学療法を実施するに当たって, 対象者の動脈硬化の 罹患率（保持率）を把握し, かつ理学療法施行患者全体 に占める割合を把握しておくことは，リスクマネジメン トにおいて有用なことである。さらに，インシデント・ アクシデントに至らせない対策を立てるための手段にな りうる情報とも考えられる。近年, 循環器疾患領域, 内 分泌代謝疾患領域の臨床で血圧脈波検査装置の有用性を 示寸報告5-7)がなされている。本研究では, 理学療法部門 で運動療法を施行する患者の動脈硬化の実態を調查し， 既往疾患との関連について検討した。

\section{II. 目 的}

血圧脈波検査装置は, 非侵襲，短時間で血管の状況を 測定でき, 動脈硬化の指標となる数值を算出できる装置 である8)

本研究では，血圧脈波検查装置により Cardio Ankle Vascular Index（CAVI）を測定し, 既往疾患の有無と比較 検討した。

\section{III. 対 象}

対象は，2006年2月から4月の間に理学療法依頼のあっ た入院患者 47 人（男性 14 人，女性 33 人，平均年齢 $72 \pm 12$ 歳）とした。対象者の内訳は，表1に示すとおりで，血圧 脈波検查装置による検査に同意した者とした。
表1 対象者内訳（人）

\begin{tabular}{|c|c|c|c|}
\hline 大分類 & 疾患名 & 小計 & 合計 \\
\hline \multirow[t]{6}{*}{ 骨関節疾患 } & 変形性股関節症 & 9 & \\
\hline & 大腿骨頚部・転子部骨折 & 8 & \\
\hline & 下肢の骨折 & 4 & \\
\hline & 変形性膝関節症 & 3 & \\
\hline & 上肢の骨折 & 2 & \\
\hline & 䅡椎椎間板ヘルニア & 1 & 27 \\
\hline \multirow[t]{4}{*}{ 脳血管疾患 } & 脳梗塞 & 7 & \\
\hline & 脳出血 & 4 & \\
\hline & 脳腫瘍 & 1 & \\
\hline & 脳挫傷 & 1 & 13 \\
\hline \multirow[t]{2}{*}{ 循環器疾患 } & 狭心症 & 2 & \\
\hline & 心臟弁膜症 & 1 & 3 \\
\hline \multirow[t]{5}{*}{ その他疾患 } & 腎不全 & 1 & \\
\hline & 多発神経炎 & 1 & \\
\hline & 結節性多発動脈炎 & 1 & \\
\hline & HILV-I & 1 & 4 \\
\hline & 合計 & & 47 \\
\hline
\end{tabular}

\section{IV. 方 法}

1. 血圧脈波検查装置の概要と測定方法

血圧脈波検查装置（フクダ電子社製VaSera VS-1000） は，血管の硬化指数をCAVIとして表している。CAVIの 標準值は9.0以下である。值は加齢によって次第に高くな るが，血圧の変動に依存することなく血管の状態（動脈 硬化の指標）を表している。なお，測定原理は，正田ら， Takakiら，Yamabeらの報告9-11)に詳しい。

血圧脈波検查装置を使用する際の測定肢位は背臥位 で，装置の操作は，両上腕，両下腿に血圧測定用のカフ を巻き, 測定ボタンを押すだけであり，約5分で完了す る。測定は簡易的で無侵襲である。測定結果は，装置の プリンターによりすぐに印字され，結果の待ち時間はな い。

2. 関連事項の収集と統計手法

CAVIの検討について, 診療録および理学療法依頼書か ら，牧田4)の報告をもとに高血圧，狭心症，糖尿病の有無 を抜粋し, 集計した。得られたデータの統計学的検討は, Mann-WhitneyのU検定に拠った。 
表2 対象者一覽表

\begin{tabular}{|c|c|c|c|c|c|c|c|}
\hline 番号 & 病名 & 高血圧 & 狭心症 & 糖尿病 & 疾病数 & CAVI 右 & CAVI 左 \\
\hline 1 & $\begin{array}{l}\text { 下肢の骨折 } \\
\end{array}$ & 0 & 0 & 0 & 0 & 4 & 4 \\
\hline 2 & 変形性股関節症 & 0 & 0 & 0 & 0 & 6.3 & 6.7 \\
\hline 3 & 上肢の骨折 & 0 & 0 & 0 & 0 & 7.4 & 7.5 \\
\hline 4 & 下肢の骨折 & 0 & 0 & 0 & 0 & 7.7 & 8.1 \\
\hline 5 & 変形性股関節症 & 0 & 0 & 0 & 0 & 7.8 & 7.7 \\
\hline 6 & 変形性股関節症 & 0 & 0 & 0 & 0 & 7.8 & 7.7 \\
\hline 7 & 下肢の骨折 & 0 & 0 & 0 & 0 & 7.8 & 7.8 \\
\hline 8 & 変形性股関節症 & 0 & 0 & 0 & 0 & 8.2 & 8 \\
\hline 9 & 大腿骨頝部・転子部骨折 & 0 & 0 & 0 & 0 & 8.9 & 8.5 \\
\hline 10 & 大腿骨䅡部・転子部骨折 & 0 & 0 & 0 & 0 & 9 & 9.2 \\
\hline 11 & 大腿骨頝部・転子部骨折 & 0 & 0 & 0 & 0 & 9.6 & 9.6 \\
\hline 12 & 変形性股関節症 & 0 & 0 & 0 & 0 & 10 & 9.9 \\
\hline 13 & 大腿骨頝部・転子部骨折 & 0 & 0 & 0 & 0 & 10.2 & 10.3 \\
\hline 14 & 下肢の骨折 & 0 & 0 & 0 & 0 & 10.5 & 11.3 \\
\hline 15 & 変形性股関節症 & 0 & 0 & 0 & 0 & 10.8 & 10.4 \\
\hline 16 & 大腿骨頝部・転子部骨折 & 0 & 0 & 0 & 0 & 11.3 & 11.9 \\
\hline 17 & 脳挫傷 & 0 & 0 & 0 & 0 & 8 & 7.8 \\
\hline 18 & 脳腫瘍 & 0 & 0 & 0 & 0 & 10 & 9.9 \\
\hline 19 & 脳梗塞 & 0 & 0 & 0 & 0 & 10.2 & 9.4 \\
\hline 20 & 脳出血 & 0 & 0 & 0 & 0 & 10.6 & 10.7 \\
\hline 21 & 脳出血 & 0 & 0 & 0 & 0 & 12 & 9.3 \\
\hline 22 & 結節性多発動脈炎 & 0 & 0 & 0 & 0 & 9.7 & 9.7 \\
\hline 23 & 頚椎椎間板ヘルニア & 0 & 0 & 1 & 1 & 8 & 8.5 \\
\hline 24 & 脳梗塞 ～～～～～～～ & 0 & 0 & 1 & 1 & 10.2 & 9.7 \\
\hline 25 & 狭心症 & 0 & 1 & 1 & 2 & 12.2 & 11.9 \\
\hline 26 & 変形性股関節症 & 1 & 0 & 0 & 1 & 8 & 8.3 \\
\hline 27 & 上肢の骨折 & 1 & 0 & 0 & 1 & 8.7 & 8.8 \\
\hline 28 & 変形性膝関節症 & 1 & 0 & 0 & 1 & 8.8 & 8.1 \\
\hline 29 & 変形性膝関節症 & 1 & 0 & 0 & 1 & 8.9 & 9 \\
\hline 30 & 変形性股関節症 & 1 & 0 & 0 & 1 & 9 & 8.7 \\
\hline 31 & 大腿骨頚部・転子部骨折 & 1 & 0 & 0 & 1 & 9.3 & 9.4 \\
\hline 32 & 変形性膝関節症 & 1 & 0 & 0 & 1 & 10.7 & 11.2 \\
\hline 33 & 大腿骨頝部・転子部骨折 & 1 & 0 & 0 & 1 & 10.9 & 10.1 \\
\hline 34 & 脳出血 & 1 & 0 & 0 & 1 & 7.8 & 8 \\
\hline 35 & 脳出血 & 1 & 0 & 0 & 1 & 9.3 & 9 \\
\hline 36 & 脳梗塞 & 1 & 0 & 0 & 1 & 9.3 & 10.1 \\
\hline 37 & 脳梗塞 & 1 & 0 & 0 & 1 & 9.9 & 9.9 \\
\hline 38 & 脳梗塞 & 1 & 0 & 0 & 1 & 10.1 & 9.8 \\
\hline 39 & 脳梗塞 & 1 & 0 & 0 & 1 & 12.9 & 9.7 \\
\hline 40 & 心臓弁膜症 & 1 & 0 & 0 & 1 & 9.3 & 9.4 \\
\hline 41 & 多発神経炎 & 1 & 0 & 0 & 1 & 10 & 9.9 \\
\hline 42 & HILV-I & 1 & 0 & 0 & 1 & 9.9 & 10.7 \\
\hline 43 & 右変形性股関節症 & 1 & 1 & 0 & 2 & 11.6 & 11.6 \\
\hline 44 & 大腿骨頚部・転子部骨折 & 1 & 1 & 1 & 3 & 10.8 & 11.5 \\
\hline 45 & 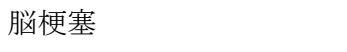 & 1 & 1 & 1 & 3 & 9.6 & 9.4 \\
\hline 46 & 狭心症 & 1 & 1 & 1 & 3 & 9.8 & 9.9 \\
\hline 47 & 腎不全 & 1 & 1 & 1 & 3 & 9.4 & 8.1 \\
\hline
\end{tabular}


表3 CAVIの多寡による平均年齢と平均疾病数

\begin{tabular}{lcccc}
\hline & 標準值群 & \multicolumn{3}{c}{ 異常值群 } \\
\hline 平均年齢 & $65.8 \pm 12.3$ & $(17)$ & $75.3 \pm 10.9$ & $(30)^{*}$ \\
平均疾病数 & 0.33 & $(15)$ & 0.94 & $(32)^{* *}$ \\
\hline
\end{tabular}

異常值は CAVI $\geqq 9.0$ とした.

( ) 内は人数

*: $\mathrm{p}<0.01, * *: \mathrm{p}<0.05$
表5 既往疾患数の多寡, 狭心症, 骨関節疾患の有無に よるCAVIの比較

\begin{tabular}{lrcc}
\hline & \multicolumn{2}{c}{ あり } & なし \\
\hline 疾患 2つ以上 & $10.5 \pm 1.2(6)$ & $9.2 \pm 1.5(41)^{*}$ \\
狭心症 & $10.5 \pm 1.2 \quad(6)$ & $9.2 \pm 1.5(41)^{*}$ \\
骨関節疾患 & $9.0 \pm 1.7(27)$ & $9.8 \pm 1.1(20)^{* *}$ \\
\hline
\end{tabular}

( )内は人数

*: $\mathrm{p}<0.01, \quad * *$ : $\mathrm{p}<0.05$
表4 疾患別の平均年齢とCAVIの標準值，異常值の割合

\begin{tabular}{lcccccr}
\hline & $\begin{array}{c}\text { 全体 } \\
\text { 平均 } \\
\text { 年齢 }\end{array}$ & $\begin{array}{c}\text { CAVI9.0 } \\
\text { 以下 } \\
\text { (人) }\end{array}$ & $\begin{array}{l}\text { 割合 } \\
(\%)\end{array}$ & $\begin{array}{c}\text { CAVI9.1 } \\
\text { 以上 } \\
\text { (人) }\end{array}$ & $\begin{array}{l}\text { 割合 } \\
(\%)\end{array}$ & 計 \\
\hline 骨関節疾患 & 70.0 & 15 & $55.6 \%$ & 12 & $44.4 \%$ & 27 \\
脳血管疾患 & 71.2 & 2 & $15.4 \%$ & 11 & $84.6 \%$ & 13 \\
循環器疾患 & 82.0 & 0 & $0.0 \%$ & 3 & $100.0 \%$ & 3 \\
その他疾患 & 79.3 & 0 & $0.0 \%$ & 4 & $100.0 \%$ & 4 \\
\hline 合計 & 71.1 & 17 & $36.2 \%$ & 30 & $63.8 \%$ & 47 \\
\hline
\end{tabular}

表6 各疾患群におけるCAVI標準值と異常值 の集計

\begin{tabular}{lccc}
\hline & 標準值 & 異常值 & 合計 \\
\hline 骨関節疾患 & 15 & 12 & 27 \\
脳血管疾患 & 2 & 11 & 13 \\
循環器疾患 & 0 & 3 & 3 \\
その他疾患 & 0 & 4 & 4 \\
\hline
\end{tabular}

異常值は CAVI $\geqq 9.0$ とした.

\section{V. 結 果}

表2は，対象者の保有疾患とCAVIデータを一覧にして 示した。CAVIの標準值を9.0以下として, 標準值群と異常 值群に分類して平均年齢と平均疾病数を比較したとこ ろ，それぞれに有意差（p<0.01, p<0.05）を認めた（表 $3)$ 。表4は, 骨関節疾患, 脳血管疾患, 循環器疾患, その 他疾患で分類した平均年齢とCAVIとその割合を示した。

高血圧，狭心症，糖尿病の3疾患のうち，2つ以上の疾 患に罹患している6人対それ以外の 41 人，狭心症あり6人 対狭心症なし41人のCAVIの比較で有意差 $(\mathrm{p}<0.01)$ を, さらに骨関節疾患 27 人対それ以外の疾患 20 人のCAVIで も有意差（ $\mathrm{p}<0.05 ）$ を認めた（表5）。

表6は, 各疾患群における標準值と異常值の集計を示し た。

\section{VI. 考 察}

CAVIの臨床的意義は，（1）血管老化の指標，（2）動脈 硬化のスクリーニング指標，（3）生活習慣病のマーカー の3点が挙げられ，加齢とともに高值となる ${ }^{12)}$ 。CAVIの 多臭と平均疾病数, さらにCAVIの多寡と平均年齢との関 係は, 異常值群の疾病数が有意に多く, 年齢が優位に高 かった。このことは, 疾患による特殊性を加味しても,
異常值群の年齢が高くなれば，疾病保有数が多くなり， 動脈硬化度が高い結果ととらえることができる。John ${ }^{13)}$ らは，動脈の硬さが高血圧進行の独立した予測因子であ ると報告している。運動療法を施行する上でのリスク因 子を増加させないためにも，血圧脈波検査装置を用いて 動脈硬化を正確に，かつ簡易的に測定できることは，意 味がある。

また，CAVIは高血圧，狭心症，糖尿病のうち2つ以上 の疾患に有意に関係した。さらに，狭心症の有無で比較 したところ，有意差を認めた。このことは，重篤な末梢 循環障害や冠動脈疾患へ発展する可能性 ${ }^{14)}$ を示してお り，加えて運動療法を実施する上で注意が必要なことを 意味している。このような場合，一般的には運動負荷テ スト等を用いるべきであるが，急性期病院では同テスト に耐えうる体力にまで到達していない患者を対象として いるため，同テストの施行はできないことが多い。例え ば，端坐位練習のような低負荷でさえもが対象者の直接 の運動負荷となるような場合も多く，本検査のような簡 便な方法でリスクマネジメントに有益な情報が一種類で も多く入手できる方法が必要なのである。

急性期病院の理学療法対象疾患は, 整形外科から依頼 される骨関節疾患が第1位である15)。今回の調査で，骨関 節疾患におけるCAVI異常值が $40 \%$ 以上を占めたことは 注目すべきことである。理学療法の依頼が骨関節疾患で 
あっても高血圧, 狭心症, 糖尿病などの疾患の保有によ り，運動負荷の質と量を考慮しなければならないことが 再確認された。循環器内科, 内分泌代謝内科と連携を図 り, 直接的な理学療法対象疾患の下に潜在的に存在する 循環器・血管病変を疑い，これらの病変のリスクマネジ メントを忘れてはならない。

今後, 我々理学療法士は, 理学療法を実施する際のバ イタルサインの事前把握とCAVIによる四肢の動脈硬化 傾向をとらえ，運動負荷がもたらすリスクが可能な限り 想定内の低侵襲で済むようなリスクマネジメントを行う ことが必要である。

なお, 本論文の要旨は, 第45回全国自治体病院学会に おいて報告した。

\section{引用文献}

1) 小野宏一: リハビリテーションスタッフが関与する医療事故 一リスクマネジメントに関する認識度調査を中心に一. 総合 リ八, 2005, 33(4): 329-334.

2) 児玉信夫:リハビリテーション部門におけるリスクマネジメ ントについて一職員の意識調查からみる現状一. 新県中病 誌, 2002, 10(1): 15-18.

3) 奥 壽郎, 小山理恵子, 佐久間智子・他 : 当院リハビリテー ション科におけるリスクマネージメントーインシデント・ア クシデント報告書の分析からの今後の課題一. 東保学誌, 2002, 5(3): 152-156.

4) 牧田茂: 総論（特集・動脈硬化予防のためのスポーツ医
学). 臨床スポーツ医学, 2004, 21(5): 477-482.

5) 沢山俊民: 血圧脈波検查装置を用いた心機能評価の有用性. 日本内科学会雑誌, 2005, 94 (臨時増刊号) : 230 .

6) 文野真樹, 日比野彰, 乾 宏行・他: 血圧脈波検査装置 (ABI form）による糖尿病患者における動脈硬化症の評価. 糖尿病, 2002, 45(4): 279 .

7) 浜崎尚文, 浦田康久, 佐伯宗弘: 血圧脈波検査装置を用いた 動脈硬化性疾患精査の試み. 脈管学, 2005, 45(10): 890 .

8) 沢山俊民 : 血圧脈波検査装置を用いた簡易心機能評価. 日本 臨床内科医会会誌，2005, 20(1):69-73.

9) 正田孝明, 八杉 巧, 檜垣實男 : 血圧に影響されない血圧脈 波検查装置CAVI-Vasera VS-1000の使用経験. 機器 ・試薬, 2005, 28(1): 81-88.

10) Takaki A, Ogawa $H$, Wakeyama $T$, et al.: Cardio ankle vascular index is a new non-invasive method to estimate arterial stiffness. 69th Annual Scientific Meeting of Japanese Circulation Society, 2005, 69(Suppl I): 526.

11) Yamabe T, Yoshizawa M, Saijo $Y$, et al.: Brachio-ankle pulse wave velocity and cardio-ankle vascular index (CAVI). Biomed Pharmacother, 2004, 58(Suppl 1): s95-s98.

12) 小菅孝明: 脈波伝播速度 PWV と新動脈硬化指標 CAVI. Mebio, 2005, 22(2): 27-35.

13) Dernellis J, Panaretou M: Aortic stiffness is an independent predictor of progression to hypertension in nonHypertensive subjects. Hypertension, 2005, 45(3): 426-431.

14) 水落和也: 末梢循環障害の成因と医学的管理. 理学療法 ジャーナル，2006, 40(12): 983-992.

15) 山野 薫, 秋山純和 : 急性期病院理学療法部門におけるリス クマネジメントの現状. 理学療法学, 2007,34(Suppl 2): 217. 